\title{
COISAS, E A MORTE QUE EXISTE NELAS. MURILO MENDES E O TRABALHO DO POETA
}

\author{
Eduardo Sterzi
}

Ao isolamento simbolizado pela figura do "Novíssimo Prometeu", cujo fígado lacerado assevera que a cicatriz social não fecha jamais (MENDES, 1994, pp. 237-238; cf. STERZI, 2006, pp. 85-107), Murilo replica, num plano suplementar, com a penetração no fluxo fantasmagórico da vida degradada. No lugar do passionalismo rasgado, há uma frieza de tom e dicção, como em "Homem trabalhando", de Poemas:

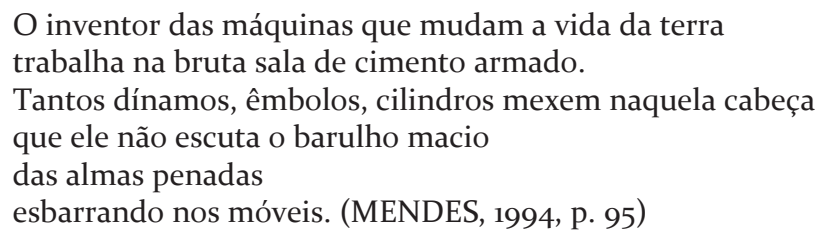

Segundo uma leitura convencional, proposta por Otávio de Freitas Júnior, o significado do poema estaria na "angústia do homo-faber, do homem só raciocínio, só cálculo”, incapacitado de ouvir o que se encontra além do mundo material (FREITAS JÚNIOR, 1941, p. 124). Com razão, o crítico nota que essa "angústia" é indistinguível de uma "ironia latente". Talvez seu rendimento hermenêutico fosse maior se enfatizasse tal ironia. Afinal, mais do que as almas oriundas de um plano transcendente ou as 
almas perdidas pelos próprios homens, são as "almas penadas" das coisas que o "inventor" não consegue escutar. A ironia está em que o homem se coisificou com tal intensidade que as coisas, por contraste, parecem, aos olhos (e ouvidos) do poeta, ter-se espiritualizado.

O Drummond de "Noite na repartição", poema de A rosa do povo, levou essa inversão de papéis ao limite, representando um pesadelo no qual o burocrata imagina que as coisas ao redor retrucam às suas lamúrias. À reclamação do Oficial Administrativo:

Sou um homem, ou pelo menos quero ser um deles! (ANDRADE, 1969, p. 108)

Drummond, comprovando um entendimento invejável da dialética entre sujeito e objeto numa tal situação, faz o Papel redarguir:

Dissolves-te na queixa, e tornado incenso, halo, paz

te sentes bem feliz enquanto eu sem consolo

espero tua brutalidade

sem a qual não vivo nem sou. (ANDRADE, 1969, p. 108)

São, porém, os Álcoois - "coisas" ingeridas pelo homem, transformadoras de sua personalidade: spirits, como se chamam em inglês - que sintetizam a promessa de embriaguez que o poeta, seja Drummond ou Murilo, há de encontrar em todas as coisas:

Somos o cristal, o mito, a estrela, em nós o mundo recomeça, as contradições beijam-se a boca, o espesso conduz ao sutil. (ANDRADE, 1969, p. 110)

"Uma coisa bela", compreende o Oficial Administrativo, ao fim da lição ministrada pelas coisas, equivale a "Uma coisa justa". Contudo, a beleza redime as coisas, e o homem tornado coisa, apenas ao passo que se conserva como espanto e expectação:

O oficial administrativo soergue o busto, suas vestes cinzentas tombam, aparece de branco, luminoso, ganha subitamente a condição humana:

Uma coisa bela?! (ANDRADE, 1969, p. 112)

A principal diferença entre "Homem trabalhando" e "Noite na repartição" está em que, neste último, ainda parece existir uma chance de o homem escapar ao enredamento pelo mundo das coisas - possibilidade negada no primeiro. No poema de Murilo, a experiência do choque é, 
paradoxalmente, abafada: o "inventor das máquinas" - e não, como em Drummond, o inventor de poemas - não escuta "o barulho macio" do atrito entre as almas e os móveis. Outra ironia. Se em Drummond o poeta preserva seu "halo", extraviado já em Baudelaire, e até mesmo se confunde com ele ("tornado incenso, halo, paz"), em Murilo são as coisas que têm "alma" - ou, com mais exatidão, revelam ser "almas penadas", e o adjetivo é relevante: o sofrimento humano, gravado nas coisas, toma a forma de uma ferida pela qual se insinua a ressurgência da aura.

O trabalho, a atividade pela qual as coisas artificiais ganham existência, é a fonte maior desse sofrimento; Murilo impreca contra o trabalho desde os primeiros até os últimos livros:

Ai trabalho, áspera vida

Para o homem, cavalo do homem,

E áspera para o cavalo. (“Atmosfera siciliana”. In MENDES, 1994, p. 565.)

Num dos poemas de O sinal de Deus, escritos entre 1935 e 1936, auge de sua conversão ao catolicismo, Murilo desdenha a revolução socialista, argumentando que ela não o atrai por falar "em nome do trabalho" ("A esposa misteriosa", in MENDES, 1994, p. 759). O homo cestheticus, de que o religioso se faz figura, mantém-se à parte: "Foice e martelo: coisa pouca para um poeta" (idem, ibidem). O trabalho distancia o homem da natureza, impedindo toda possibilidade de retorno ao seu regaço acolhedor:

É o homem que trabalha enquanto os vegetais sonham,

o mar se espreguiça,

os minerais dormem a vida inteira.

$[\ldots]$

Os cheiros da terra sumiram,

cemitério, fogos-fátuos, coração vazio, as cordas da vontade estalam.

Além das fronteiras do espírito, mais além!

O olho fixo do demônio determina a paisagem. ("Sonata sem luar, quase uma

fantasia”. In MENDES, 1994, pp. 103-104.)

O trabalho é um dom demoníaco:

Demônios grandes

trabalham na planície, nas montanhas,

nos arranha-céus,

constroem o trabalho dos homens ("Vida dos demônios". In MENDES, 1994, p. 104) 
No entanto - e eis uma perfeita compreensão do caráter bífido do esforço intelectual, de seu intercâmbio entre espírito e matéria -, mesmo a poesia é assombrada pelas tropas infernais, porquanto seja um trabalho: os demônios "ajuntam imagens e reflexos na cabeça dos poetas" (idem, p. 104).

A palavra "trabalho" provém de um verbo do latim vulgar, tripaliare, que significava martirizar com o tripalium (instrumento de tortura). Entre os sentidos atuais de "trabalhar", ainda está o de atormentar, afligir. E o trabalhador, de fato, martiriza as matérias-primas. Uma pedra trabalhada deixa de ser pedra para tornar-se algo útil, e transmuta-se em fantasma - de pedra a espectro - ao ser forçada a passar do mundo natural para o mundo dos homens. A utilidade é, em certa medida, a morte das coisas. Ao mesmo tempo, contudo, é oferta de nova vida, embora esta seja uma vida espectral. Entretanto, não somente as coisas despedem-se de sua essência por meio do trabalho; o homem também se faz "forma distanciada de sua substância" ("Naturezas mortas". In MENDES, 1994, p. 422).

Marx desnudou este processo, ao constatar que o objeto produzido pelo trabalhador aparece-lhe como um "ser estranho", como um "poder independente", e que o trabalhador, ao produzir os objetos, produzia a si mesmo e seu trabalho como objetos (MARX, 1995, p. 105). A valorização do mundo das coisas e a desvalorização do mundo humano são processos simultâneos e especulares. Para Marx, produzir um objeto equivale a perdê-lo e, concomitantemente, deixar-se servilizar por ele. O objeto fantasma torna-se tão mais aterrorizante porque seu único vínculo com o ser humano não é mais o cordão umbilical que ligava o artesão, por exemplo, ao seu produto, e que, na modernidade, teima em reaparecer na singularidade das obras de arte (Marx, estilista do texto, subscrevia o credo de Buffon: "Le style, c'est l'homme" [MARX e ENGELS, 1974, p. $\left.71^{1}\right]$ ), mas os grilhões que o objeto prende ao trabalhador. "A alienação do trabalhador em seu produto significa não somente que seu trabalho se converte em um objeto, em uma existência exterior, senão que existe fora dele, independente, frente a ele; que a vida que ele emprestou ao objeto enfrenta-lhe como coisa estranha e hostil" (MARX, 1995, p. 106). Marx compara essa alienação com a entrega religiosa: quanto mais o homem deposita seu vigor nos objetos ou em Deus, mais poderoso torna-se este

1 Originalmente, nas "Notas sobre as recentes instruções prussianas relativas à censura". A frase de Buffon foi extraída do Discurso sobre o estilo, proferido em 1753 na Academia Francesa, e aparece em francês no texto de Marx. 
mundo estranho que ele cria e menos ele é dono de si mesmo. Como tentativa de recuperar a vida para além da reificação, invocando a teologia negativa da arte, origina-se o interesse pelos objetos de arte e pela paisagem cultural nos livros finais de Murilo.

No entanto, Murilo sabe que, para não fugir à história e à sua verdade, o artista moderno deve mimetizar, na obra que produz, a alienação do trabalhador. Este é o sentido da confissão engastada no "Murilograma a Guido Cavalcanti", na qual se demarcam as fronteiras entre dois momentos altamente diferenciados da atividade artística, aquele em que vivia Cavalcanti, mestre de Dante Alighieri, e o momento vivido pelo próprio Murilo:

Agora / opacos / espectrais

comunicantes em superfície

Com téssera de alienados

Nem criamos grafitos: grafito se é. (MENDES, 1994, p. 667)

Murilo decerto pensava em manifestações artísticas contemporâneas à redação do poema (1963), tais como os happenings e a body art, ao dizer que agora "grafito se é". Em sua própria obra, o título dos "Murilogramas" já vale por um manifesto sobre a necessidade de coisificar o eu como exercício irônico de crítica social. Em vez do dolce stil nuovo, instaura-se um amaro stil nuovissimo.

O trabalho artístico pode ser visto, dialeticamente, como o modelo ímpar da imbricação entre vida e morte no martírio da matéria. Como frisa Terry Eagleton, as considerações sobre a mercadoria, na teoria econômica de Marx, delineiam os traços de "uma caricatura amedrontadora do objeto artístico autêntico, ao mesmo tempo reificada num objeto brutamente singular e virulentamente antimaterial, na sua forma; densamente corpórea e fugidiamente espectral" (EAGLETON, 1993, p. 155). A despeito de tal aproximação, conforme ressalva Eagleton, o objeto estético retém a integridade de "artefato pervertido", relativamente refratário ao comércio, à exposição fetichista. Mas não é certo, sobretudo na modernidade, que o quadro, a canção ou o poema não internalizem, em sua estrutura, algo daquele sublime negativo que Eagleton, perseguindo as indicações de Marx, descobre na dinâmica infatigável (e agressivamente estimulante à imaginação) do capitalismo, em sua inabalável dissolução de formas e identidades numa voragem puramente quantitativa:

O movimento da mercadoria é [...] uma forma do "mau" sublime, uma cadeia metonímica que não para, na qual cada objeto refere-se ao próximo, e este 
ao próximo, indefinidamente. Como no sublime matemático de Kant, esta acumulação infinita da pura quantidade subverte qualquer representação estável, e o dinheiro é o seu principal significante. [...] O dinheiro para Marx é uma espécie de sublime monstruoso, um significante infinitamente proliferante que perdeu toda relação com o real, um idealismo fantástico que bloqueia todo valor específico tanto quanto aquelas imagens convencionais do sublime - o oceano furioso, os despenhadeiros - mergulham toda identidade particular em sua expansão sem limites. (EAGLETON, 1993, p. 158)

Podemos indagar se Murilo estava consciente desta proliferação implícita no signo do dinheiro ao propô-lo como termo final de um esvaziamento do eu definidor de sua identidade:

Coisa ínfima, quero ficar perto de ti:

Pássaro que fugiu da tempestade.

Eu sou uma moeda que Deus deixou rolar no chão (MENDES, 1994, p. 303)

Se a resposta for positiva, o título do poema, "O átomo", etimologicamente o indivisível, conjugado à vindicação da origem divina da moeda-homem, deveria ser compreendido como uma esplêndida ironia. E se o sujeito e mesmo a paisagem, antes o palco estável onde se representava o drama da vida, precipitam-se na vertigem da mercadoria, a forma do poema autêntico, congenitamente sensível aos abalos da história, não há de permanecer inalterada. Sendo assim, deveríamos revisitar o poema "Estrelas" e relê-lo a partir da observação de Benjamin segundo a qual as estrelas, em Baudelaire, representam "a imagem ardilosa da mercadoria. São o sempre igual em grandes massas" (BENJAMIN, 1989, p. 154):

Há estrelas brancas, azuis, verdes, vermelhas.

Há estrelas-peixes, estrelas-pianos, estrelas-meninas,

Estrelas-voadoras, estrelas-flores, estrelas-sabiás.

Há estrelas que veem, que ouvem,

Outras surdas e outras cegas.

Há muito mais estrelas que máquinas, burgueses e operários:

Quase que só há estrelas. (MENDES, 1994, p. 269)

"Estrelas" extrapola a mera representação da infinitude dos astros ao valer-se daquele recurso que, na retórica de Longino, era designado áuxesis, método quantitativo para alcançar uma grandeza literária semelhante ao sublime, uma espécie de sublime degradado: ocorre "quando os assuntos e os debates admitem, por períodos, numerosos inícios e numerosas pausas, e quando elementos trazendo, em acúmulos 
sucessivos, reforço a outros elementos produzem, sem descontinuidade, grandeza por gradação” (LONGINO, 1996, p. 62). O texto em sua máxima reificação: "Quase que só há estrelas", e o poeta figura esta voragem mediante a repetição excessiva da palavra "estrelas", encadeando suas múltiplas aparições numa enumeração que, na esteira de Leo Spitzer, nos sentiríamos tentados a designar "caótica". Mas, com tal adjetivo, negligenciaríamos a sutileza e a atenção exigidas pela poesia de Murilo Mendes.

Spitzer, em seu estudo clássico sobre a "enumeração caótica", identificou Walt Whitman como o primeiro poeta a introduzir o caos moderno na imemorial técnica enumerativa, encontrada já nos Vedas indianos, nos gregos, na Bíblia, nos barrocos espanhóis. Como ilustra o crítico, o "vigoroso assíndeton" de Whitman aproxima com violência as coisas mais díspares, "como uma criança que estivesse folheando o catálogo de uma grande loja e anotando em desordem os artigos que o acaso pusesse sob sua vista" (SPITZER, 1974, p. 258). Não se trata de uma analogia sugerida por uma imaginação pitoresca. Numa nota agregada ao texto, Spitzer propõe uma explicação "sociológica” para o procedimento:

\footnotetext{
Não há nenhum anacronismo em referir as enumerações de Whitman - o "poeta de catálogo" (Katalogdichter), segundo a expressão de Eulenberg - aos grandes armazéns de varejo. Próximo a 1855, isto é, a data de publicação de Leaves of Grass, é quando começa o enorme desenvolvimento destes bazares ocidentais, as department stores, produzido pela acumulação de riqueza e pela expansão do comércio e dos meios de transporte. (idem, p. 258n)
}

O americano Whitman tinha, porém, como ressalva Spitzer, um precursor europeu entre os romancistas: Balzac (a precedência da prosa, aliás, não é casual: o mundo da mercadoria coincide com o mundo da prosa). As enumerações caóticas da Comédie humaine descendem das listagens de Rabelais, mas também se inspiram na diversidade das mercadorias oferecidas pelas lojas de departamentos. O primeiro grand magasin da capital francesa, La Ville de Paris, foi inaugurado em 1834; mesmo ano (fato olvidado por Spitzer) em que Balzac, pela primeira vez, cogitou estabelecer ligações entre suas narrativas, fazendo as personagens já criadas reaparecerem em outras obras, e manifestou o desejo de unificá-las em três títulos coletivos - Estudos de costumes, Estudos filosóficos e Estudos analíticos (só em 1842 chegou ao título mais abrangente) (cf. RÓNAI, 1957, p. 16).

A enumeração caótica, conforme Spitzer argumenta, é consequência e exacerbação da "mescla estilística" (Stilmischung) estudada por 
Auerbach, especialmente no romance realista do século XIX, e que consiste no reconhecimento do elemento trágico na existência cotidiana, e não apenas, como rezava a rígida distinção de classes sociais e estilos do classicismo, entre os aristocratas (cf. AUERBACH, 1971, pp. 395-430). A transição da mescla estilística para a enumeração caótica corresponde à transição da "democracia humana" para uma paródica e ameaçadora "democracia das coisas" (os termos são de Spitzer). O homem sente essa nova "democracia" - profetizada por Marx quando fala do "poder independente" dos objetos frente aos trabalhadores - como uma autocracia. O sonho das mercadorias, sonho que elas talvez compartilhem com as obras de arte (basta pensar nas imagens aquiropoéticas), é a autogeração em moto-contínuo, uma rigorosa imaculada concepção, sem as nódoas deixadas por mãos humanas. Mostra-se assim a face reversa, assustadora, do autotelismo desenfreado das coisas exoneradas do vínculo original com a natureza e, por consequência, dessas coisas feitas de palavras que chamamos obras literárias:

\begin{abstract}
Nesse mundo que Deus criou, segundo o relato do Gênesis, com ordem perfeita e com a precisão lógica de um espírito enciclopédico e metódico (um dia cria as plantas, outro os peixes, outro as bestas e animais da terra), as coisas chegam a fazer-se autônomas e começam a redemoinhar-se em torno ao homem, mesclando-se com as criaturas, com o homem mesmo, com suas ferramentas, suas ideias e seus sentimentos, e até com suas palavras: o torvelinho de palavras, de slogans, de frases feitas, somar-se-á nos romances de Joyce ou Döblin aos torvelinhos de coisas que revoluteiam ao redor do homem moderno, e pode fazer-se mais "real", mais obsessivo que a realidade mesma das coisas. (SPITZER, 1974, p. 288)
\end{abstract}

Insistindo na hipótese de Spitzer de que a enumeração caótica reflete o fascínio da mercadoria, teremos de observar que a primeira loja de departamentos do Rio de Janeiro surgiu na década de 1870 (NEEDELL, 1993, p. 191). Contudo, desde 1808 , com a chegada da família real portuguesa, o comércio de artigos de luxo já se estabelecera na cidade, enraizando-se, a partir de 1820, na Rua do Ouvidor. A rua toda constituía uma espécie de magasin extensivo, provendo a mescla de ofertas de produtos e convites ao lazer que é essencial para o fetichismo da mercadoria, tal como analisado por Marx e Benjamin. Com a construção da Avenida Central, na reforma de Pereira Passos, para ali se transferiu a efervescência mercantil. A recordação daquelas vitrines e das pessoas que se congraçavam à sua frente, como fiéis diante de novos oratórios, certamente alimentava a nostalgia de Murilo pela "cidade deliciosa, pacata”. Sua poesia constrói-se pelo choque entre essa visão apaziguada, 
e - é preciso que se diga, considerando-se a maneira como se chegou a tal paz - fundamentalmente falsa, e uma simultânea visão contrária, e verdadeira, agitada por um estremecimento semelhante àquele subjacente à "enumeração caótica". O próprio Murilo estava consciente do conceito proposto por Spitzer, tanto que, no programático "Texto de consulta”, uma das sínteses de sua poética madura, o refuta:

\author{
Querendo situar objetos \\ Criamos um elenco vertical. \\ Enumeração caótica? \\ Antes definição. \\ Catalogar, próprio do homem. (MENDES, 1994, p. 739)
}

Entre "enumeração caótica" e "definição" há sobretudo uma diferença, e é a ideia de fim inerente ao ato de definir. Neste sentido, é emblemático o verso final da primeira estrofe de "Parábola":

A rua, o rolar de remota carruagem;

Intacto o piano, exausta a biblioteca;

A infância em ombrela rosa

E a rosa adormecida no esmalte;

A tradição da febre, a asa fria do pássaro

Que não passa, que subsistirá no testemunho:

Eis o que considero por enquanto. (MENDES, 1994, p. 549)

Esse verso estabelece a pausa que permite à série funcionar como "definição" de algo: talvez a infância do poeta (o que também tem valor de emblema). Determina o limite imposto à infinitude potencial e previsivelmente entrópica. Para Aristóteles, mimetizar é inato ao homem; para Murilo, "catalogar" é que lhe é "próprio" (de "inato" a "próprio", aliás, rompe-se a ilusão de naturalidade: o destino revela-se tarefa, "ofício humano"2). "Catalogar" pressupõe katá, prefixo denotador de regressão e completeza, e logos, mal traduzindo (com o risco de perder as fulgurantes conotações filosóficas e religiosas), palavra. Catalogar é definir, alcançar, regressivamente, o fim-início das coisas pela integridade exaustiva da palavra. É contestar o ilusório presente perpétuo reinante no mundo dos objetos artificiais, sem, todavia, submeter-se novamente ao domínio da natureza. O homem que apenas mimetiza, em plena

2 Ofício humano é o título do primeiro dos dois livros de que se compõe Poesia liberdade - e tornou-se também o título de uma antologia em francês, Office humain, trad. Dominique Braga e Saudade Cortesão, Paris: Seghers, 1954. 
modernidade, referenda a autonomia das coisas e seu primado sobre os homens; o homem que cataloga põe em dúvida a própria existência das coisas. Ingressamos outra vez no país dos fantasmas.

Lúcia Miguel Pereira foi provavelmente quem primeiro assinalou a estratégia retórica que melhor realiza o afã delimitador do catálogo, sem entender de todo, entretanto, sua real motivação, seu alcance e seu significado. "Murilo Mendes", dizia ela, "é a negação do conceito de Théophile Gautier, que define o poeta como aquele para quem as coisas existem. Para ele, elas não existem. E dessa inexistência é que tira a sua poesia (PEREIRA, 1992, p. 136)". Para a poesia "descarnada" de Murilo, adverte a crítica, só interessa o "espírito". Alvaro Lins, seguindo a mesma linha, afirmou que, para Murilo, "o mundo físico não existe poeticamente": o poeta só consideraria os objetos em sua existência suposta num plano metafísico (LINS, 1963, p. 47). Porém, é de outra ordem a inexistência das coisas em Murilo. Foi Antonio Candido quem, com a segurança e presciência habituais, apreendeu o cunho crítico e dialético desse gesto poético, ao reparar, em ensaio sobre o poeta, que, "na comparação, sobretudo em sua forma mais radical, a metáfora, o mundo está e não está presente" (CANDIDO, 1993, p. 30). Candido está glosando um célebre pensamento de Pascal, e, se tivesse ido um pouco além na paráfrase, desvelaria aquela ambivalência sublime que Murilo fez tão sua: "Figura comporta ausência e presença, prazer e desprazer" (PASCAL, 1984, p. 207). Em outro texto, Candido volta ao tópico, ao comentar que Murilo parece desejar uma "poética da ausência" (CANDIDO, 1985, p. 90). A expressão é exata.

Com ela, o crítico denomina o artifício pelo qual Murilo, em "O pastor pianista”, de As metamorfoses, troca os elementos esperados num poema pastoral por elementos inesperados e, sobretudo, aparentemente ilógicos e arbitrários: o deserto toma o lugar do prado; os pianos, o lugar das ovelhas. A "poética da ausência” não é apenas uma atualização das impossibilia ou adynata, embora às vezes também sirva ao propósito daquelas de censurar a degradação moral de sua época, declarando a sua inconformidade e reafirmando a esperança de um mundo diferente, pela inversão das posições e funções habitualmente ocupadas e desempenhadas pelos seres e objetos na realidade (cf. CURTIUS, 1996, pp. 139-144). Na poesia de Murilo, a relação entre a figura poética aparente e o termo oculto não se funda na mera oposição entre ambos - processo que conserva um compromisso semântico entre os dois elementos -, mas na surpresa - que cinde, ou, pelo menos, torna muito mais complexa, qualquer ligação entre os elementos. Contudo, por mais 
imprevisíveis e até gratuitas que as figuras pareçam, elas jamais são fruto da imediatez da escrita automática. O poeta não abdica do controle sobre os maquinismos da imaginação, e a lei retórica mais severa dessa escrita reticular prevê que o termo ausente deve ser tão significante quanto o termo presente, como se "a riqueza das palavras possíveis que o poeta rejeitou, e ficaram dormindo no dicionário, fluísse encachoeirada entre as muretas limitadoras das frases que afinal compôs" (CANDIDO, 1985, p. 88). Não podemos esquecer a consequência pragmática que Antonio Candido atribui a esse procedimento: ao desfiar os nexos usuais e criar nexos novos entre os seres e objetos da realidade, a "poética da ausência" provoca uma espécie de "choque" na percepção do leitor, estimulando-o a "tomar conhecimento de uma realidade insuspeitada" (CANDIDO, 1985, p. 90).

Há um depoimento de Murilo que bem caracteriza a maneira como ele se desvencilha da lógica figurativa da mercadoria, sem, no entanto, abdicar da energia proporcionada por sua vertigem: "Manipulo sempre, além do verbo comprar, o verbo perder" ("Microdefinição do autor". In MENDES, 1994, p. 46). Na modernidade, o poeta substitui o místico como ascético virtuose da perda. "Sabendo que a figura deste mundo passa breve", proclama Murilo, "o místico usa as coisas como se não as possuísse" (MENDES, 1996, p. 129). Só o poeta versado na rotina do choque está apto para responder à necessidade de que o místico se converta em "homem de ação". "Não há mais desertos", observa Murilo. "Atribuíamse outrora muitos fenômenos místicos ao ambiente favorável criado pelo retiro, à sombra e à solidão; não nego a importância desses fatores. Mas como não há mais desertos, os místicos modernos deverão trabalhar em ambientes povoados, e muitas vezes ruidosos" (MENDES, 1996, p. 130). O encasulamento na dureza da palavra conforma a tentativa de isolar-se do fluxo tumultuário da vida para não perder definitivamente a voz, única propriedade do poeta. "Viver morrendo", de A poesia em pânico, enuncia essa ânsia:

Preciso me revestir da estabilidade da pedra

Para ver o movimento imóvel, o deserto sem cardo... (MENDES, 1994, p. 302)

Neste poema, a força necessária à contemplação da terra devastada é condicionada à "paciência" e à "esperança" cristãs. Porém, só em Siciliana Murilo conquista de fato a estabilidade pétrea, almejada desde sempre, ao abeirar-se às coisas com o olhar cristalino e desencantado do homem trágico. São as irrupções temporãs e isoladas dessa tragicidade, obtida finalmente à custa da madureza e da aproximação da própria morte, 
que lhe permitem extrair da agressividade do mundo a força de que precisa para enfrentá-lo. O deserto torna-se uma figura da interioridade do poeta, preparada para enfrentar o torvelinho sem ser tragada. O que Murilo diz de Maliévitch poderia ser carreado para sua própria descrição:

Nomeia o deserto ao qual chegou

Pelo esvaziamento do objeto. (“Grafito para Casimir Malevitch”. In MENDES, 1994, p. 659)

O nome desse deserto é modernidade, e é também Murilo Mendes. Se a imagem da planície erma, aliviada de qualquer vida, singular waste land com o Pão de Açúcar ao fundo, ocupa o reverso da moeda, a figura de Orfeu, dilacerado pelas bacantes mas ainda a cantar, adorna a face. Murilo a evoca diversas vezes, mas com especial adequação num poema em homenagem a Drummond, no qual, sob o signo do cantor inigualável, se conjumina ao autor de Fazendeiro do ar (título indicativo da fraternidade na fantasmagoria). Primeiro, Murilo "cataloga" o cuidado de ambos com as mesmas "Antigaláxias da náusea":

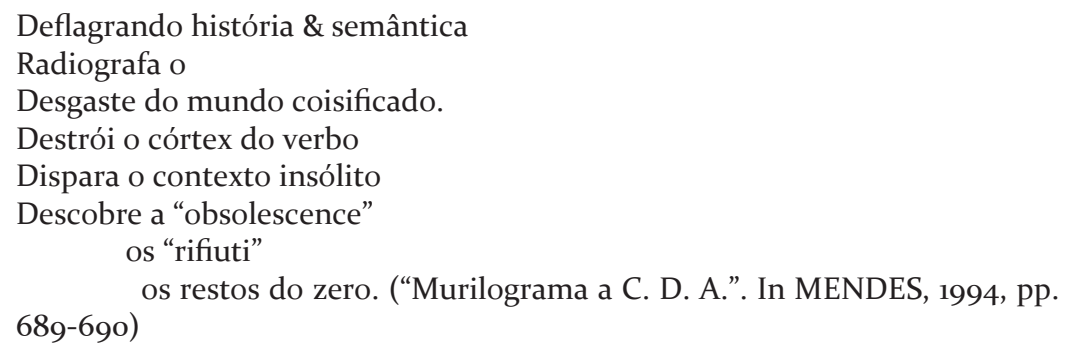

Depois, identificando a recolha dos "restos" com o canto resistente à dispersão dos membros de Orfeu, reitera a contração final, em que as ruínas do "mundo coisificado" tomam a forma do poema ("ságoma": termo italiano para molde, modelo, esboço, rascunho, aportuguesado por Murilo):

Resta a ságoma de Orfeu

Com discurso ou sem. (idem, p. 69o)

Eis uma ostensiva autocitação. Refere-se ao poema "Exergo", de Convergência:

Lacerado pelas palavras-bacantes

Visíveis tácteis audíveis

Orfeu 
Impede mesmo assim sua diáspora

Mantendo-lhes o nervo e a ságoma. (MENDES, 1994, p. 625)³

Murilo condensa, na estrutura simétrica e asfixiante de "Paisagem", a tensão entre o eu desértico, cultivador da perda, e o cenário exterior cuja vacuidade é salientada por meio do discurso poético, exercício ativo da perda:

\author{
Do sino vazio \\ Voam esquadrilhas de pássaros. \\ No oco da lâmpada \\ Irrompe a floresta \\ (Ninguém para me asfixiar). \\ O quarto caminha \\ Até o fundo do horizonte. \\ O espelho se contrai, \\ Vãos ornamentos, \\ Pernas tronco soluços. (MENDES, 1994, pp. 390-391)
}

Há uma incessante e muda comunicação entre o quarto e o ambiente "natural" externo (as aspas vão por conta do fato de que possivelmente a "floresta" e as "esquadrilhas de pássaros" não sejam mais do que figuras irônicas do mundo artificial, flagrado em sua ausência). A primeira e a terceira estrofes contêm imagens de expansão; a segunda e a quarta, imagens de contração. Vemos aí uma imitação do fôlego que, parece lamentar o poeta, ninguém se dispõe a sufocar. Por certo, subjaz a esse poema uma volúpia da asfixia, compreendida talvez como máxima concentração da voz. Não é acidental que a última imagem seja uma imagem de contração, e que no espelho (côncavo, com certeza) reúnamse os reflexos de partes do corpo humano (Orfeu despedaçado) e "soluços" (o poema por dizer). Comentando os textos que viriam a ser publicados em As metamorfoses ${ }^{4}$, Otávio de Freitas Júnior assinala que, neles, a

3 Os seus versos são repetidos sob o título de "Fim e começo" como uma espécie de coda da segunda seção do livro, sendo-lhes acrescentada, em versaletes, apenas a palavra "Fim" seguida de ponto de interrogação (p. 703); assim, Murilo afirma a unidade entre os "Grafitos" e os "Murilogramas" e distingue-os dos poemas da terceira seção de Convergência, "Sintaxe".

$4 \mathrm{O}$ crítico refere-se ao livro pelo título provisório Parábolas, descartado, o qual não deve ser confundido com o posterior Parábola. 
poesia de Murilo se “cristaliza”, tornando-se uma "sublimação de beleza concreta"; a "violência dramática" de sua obra anterior é permutada pelo conforto possível das figuras: "Já alguém notou que os poetas, como os meninos, se consolam com imagens” (FREITAS JÚNIOR, 1941, p. 134). No limite da respiração reprimida, o homem tenta recuperar a familiaridade com as coisas, interiorizando-as, assimilando-as, dramatizando a perda para superar a situação em que era vítima passiva para assumir, depois de compulsivas repetições, um papel ativo. Quem melhor tratou esta questão foi o Freud de Além do princípio do prazer. Relembremos seu assombro frente à recorrência dos sonhos que acompanham as neuroses traumáticas (os quais se distinguem por levar o paciente sempre de novo à ocasião do trauma) e suas especulações acerca do jogo do fort-da encenado por seu neto Ernst, de dezoito meses, que consistia em atirar longe um cilindro de madeira preso a um barbante, dizendo ao mesmo tempo um o prolongado (interpretado pelo avô como fort, "ido"), e em seguida puxar o cilindro de volta, saudando-o com um contente "da" ("ali”) - perfazendo, assim, uma reprodução lúdica do ciclo de ausência e retorno da mãe, e, em certa medida, vingando-se dela por abandoná-lo (cf. FREUD, 1988, pp. 23-27).

Numa resenha de um livro sobre a história dos brinquedos, Benjamin retoma a "compulsão à repetição" teorizada por Freud:

toda experiência profunda deseja, insaciavelmente, até o fim de todas as coisas, repetição e retorno, restauração de uma situação original, que foi seu ponto de partida. "Tudo seria perfeito, se pudéssemos fazer duas vezes as coisas": a criança age segundo essas palavras de Goethe. Somente, ela não quer fazer a mesma coisa apenas duas vezes, mas sempre de novo, cem e mil vezes. Não se trata apenas de assenhorear-se de experiências terríveis e primordiais pelo amortecimento gradual, pela invocação maliciosa, pela paródia; tratase também de saborear repetidamente, do modo mais intenso, as mesmas vitórias e triunfos. O adulto alivia seu coração do medo e goza duplamente sua felicidade quando narra sua experiência. A criança recria essa experiência, começa sempre tudo de novo, desde o início. Talvez essa seja a raiz mais profunda do duplo sentido da palavra alemã Spielen (brincar e representar): repetir o mesmo seria seu elemento comum. A essência da representação, como da brincadeira, não é "fazer como se", mas "fazer sempre de novo", é a transformação em hábito de uma experiência devastadora. (BENJAMIN, 1987, p. $\left.253^{5}\right)$

A ideia da poesia como repetição de uma experiência de perda vivencial e restituição simbólica já está preconizada, em Murilo, no mito

5 Minha atenção foi atraída para este texto de Benjamin por uma observação de Roberto Calasso (CALASSO, 1997, p. 146). 
pessoal do cometa Halley. Esta noção ocupa uma posição central em sua poética implícita. Merquior, analisando sua obra em diálogo com um ensaio de Sartre sobre a narrativa de Kafka e Maurice Blanchot (SARTRE, 1985, pp. 93-110), propôs: "O habitante do visionário não é, como o do fantástico, um burocrata medular. Ele perde-e-recupera, perde-masrecupera o seu status humano de detentor supremo de finalidades" (MERQUIOR, 1996, p. 79). Aqui, não é propriamente uma coisa o que Murilo perde, mas o gasoso âmago de sua identidade como homem. No entanto, no momento mesmo em que perde seu "status humano" para depois recuperá-lo (o otimismo do crítico justifica-se? O poeta moderno será mesmo um herói ou somente alguém que representa o papel do herói?), Murilo o coisifica. Transforma-o em algo passível de barganha, algo cuja ausência talvez possa ser compensada pela aquisição de outro objeto. Esta é a enganadora - mas tantas vezes eficaz - promesse de bonheur implícita na sedução da mercadoria (e reafirmemos, novamente, a índole modelar da lógica da mercadoria para a modernidade).

Se, conforme Merquior, a realização do nobre destino humano do poeta depende da reconquista do que foi perdido, do preenchimento de uma carência situada no cerne do $e u$, por outro lado não é certo que a recuperação final, quando o objeto perdido é, em maior ou menor grau, alheio ao poeta, seja necessária, ou possível. A persistência da perda pode converter-se em estranha fonte de prazer (a violência do trauma, como anota Freud, causa excitação sexual ao neurótico; o "fort" de Ernst, mesmo anuviado pelo rancor infantil, já é um balbucio de alegria, independentemente da restituição posterior do cilindro lançado além). A saciedade quebra o encanto da ausência. A virtude de Murilo avalizada por Merquior ao contrapô-lo ao "burocrata medular" - reside em sublinhar o teor barbaramente moderno que o gozo unheimlich, ou masoquista, tinha em sua poesia.

\section{REFERÊNCIAS BIBLIOGRÁFICAS}

ANDRADE, Carlos Drummond de. Reunião. Rio de Janeiro: José Olympio, 1969.

AUERBACH, Erich. "Na mansão de la Mole”. In Mimesis. A representação da realidade na literatura ocidental. Trad. Suzi Frankl Sperber. São Paulo: Perspectiva, 1971, pp. 395-430.

BENJAMIN, Walter. "Brinquedo e brincadeira. Observações sobre uma obra monumental”. In Magia e técnica, arte e política. Trad. Sergio Paulo Rouanet. São Paulo: Brasiliense, 1987, pp. 249-253. 
BENJAMIN, Walter. "Parque central". In Charles Baudelaire. Um lírico no auge do capitalismo. Trad. José Carlos Martins Barbosa e Hemerson Alves Baptista. São Paulo: Brasiliense, 1989.

CALASSO, Roberto. "Esconderijos”. In Os 49 degraus. Trad. Nilson Moulin. São Paulo: Companhia das Letras, 1997.

CANDIDO, Antonio. “O mundo desfeito e refeito”. In Recortes. São Paulo: Companhia das Letras, 1993.

. "Pastor pianista/pianista pastor". In Na sala de aula. Caderno de análise literária. São Paulo: Âtica, 1985.

CURTIUS, Ernst Robert. “O mundo às avessas”. In Literatura europeia e Idade Média latina. São Paulo: Hucitec: Edusp, 1996.

EAGLETON, Terry. A ideologia da estética. Trad. Mário Sá Rego Costa. Rio de Janeiro: Jorge Zahar, 1993.

FREITAS JÚNIOR, Otávio de. "Murilo Mendes". In Ensaios de crítica de poesia. Recife: Norte, 1941.

FREUD, Sigmund. "Além do princípio de prazer". In Além do princípio de prazer. Psicologia de grupo e outros trabalhos. Trad. Christiano Monteiro Oiticica. Rio de Janeiro: Imago, 1988.

LINS, Alvaro. "Murilo Mendes: o positivo e o negativo na originalidade". In Os mortos de sobrecasaca. Rio de Janeiro: Civilização Brasileira, 1963.

LONGINO, Do sublime. Trad. Filomena Hirata. São Paulo: Martins Fontes, 1996.

MARX, Karl. Manuscritos: economía y filosofía. Trad. Francisco Rubio Llorente. Madrid: Alianza, 1995.

MARX, Karl. e ENGELS, Friedrich. Sobre literatura e arte. Trad. Albano Lima. Lisboa: Estampa, 1974.

MENDES, Murilo. Poesia completa e prosa. Org. Luciana Stegagno Picchio. Rio de Janeiro: Nova Aguilar, 1994. . Recordações de Ismael Nery. São Paulo: Edusp; Giordano, 1996.

MERQUIOR, José Guilherme. "Murilo Mendes ou a poética do visionário”. In Razão do poema. Rio de Janeiro: Topbooks, 1996.

NEEDELL, Jeffrey D. Belle époque tropical. Sociedade e cultura de elite no Rio de Janeiro na virada do século. Trad. Celso Nogueira. São Paulo: Companhia das Letras, 1993.

PASCAL, Blaise. Pensamentos. Trad. Sérgio Milliet. São Paulo: Abril Cultural, 1984.

PEREIRA, Lúcia Miguel. “Jorge de Lima e Murilo Mendes: harmonia e diferenças”. In A leitora e seus personagens. Rio de Janeiro: Graphia, 1992. 
RÓNAI, Paulo. Balzac e A comédia humana. Porto Alegre: Globo, 1957.

SARTRE, Jean-Paul. "Aminadab o de lo fantástico considerado como un lenguaje". In Escritos sobre literatura. Trad. Luis Echávarri, v. 1. Madrid: Alianza; Buenos Aires: Losada, 1985 .

SPITZER, Leo. "La enumeración caótica en la poesía moderna". In Lingüística e historia literaria. Madrid: Gredos, 1974.

STERZI, Eduardo. "Murilo carioca. Espaço, metamorfose, catástrofe, poesia". In Letterature d'America, 112 (2006). 